Pakistan Journal of Applied Economics, Vol.27 No.1, (41-66), Summer, 2017

\title{
GDP FLUCTUATIONS AND LONG-RUN ECONOMIC GROWTH: A Study of Selected South Asian Countries
}

\author{
Ghulam MOHEY-UD-DIN* \\ and Muhammad Wasif SIDDIQI**
}

\begin{abstract}
This paper studies the relationship between GDP fluctuations and long-run economic growth by using macro-panel approach (with small $\mathrm{N}$ and large $\mathrm{T}$ ) in a panel of five selected South Asian countries (SSAC) including Bangladesh, India, Nepal, Pakistan and Sri Lanka, over a period of 1980-2010. For this purpose, modern non-stationary panel techniques such as the cross section dependence test, unit root test under cross sectional dependence, panel cointegration and Group Mean Fully Modified OLS (GM-FMOLS) estimation are applied. The study finds a significant long-run cointegrating relationship between GDP fluctuations and long-run growth in the SSAC and GM-FMOLS estimates and shows that this link is negative. It indicates that GDP fluctuations have a significant negative impact on long-run growth in the SSAC and these fluctuations of GDP may be detrimental for long-run growth in developing countries. Therefore, the governments of such countries shouldn't rely on growth-oriented policies only but should equally focus on managing these fluctuations in GDP to achieve sustained and stable growth rate.
\end{abstract}

\section{Introduction}

According to the traditional viewpoint, the business cycle and economic growth are considered two isolated fields in macroeconomics [Ramey and Ramey (1995), Martin and Rogers (2000), Siegler (2005), Tochkov and Tochkov (2009), Lee (2010). Commonly, it is believed that fluctuations in GDP are transitory in nature and these short-run deviations from trend have no correlation or causal-link with long-run economic growth. Thus, the syllabus of macroeconomics is normally separated into growth theory and business-cycle theory. However, this belief has been challenged by recent studies which have found significant relationship between growth and volatility [Fatás (2002), Hnatkovska and Loayza (2004)]. A negative link was found between volatility and growth in the seminal papers of Ramey and Ramey (1995) and then Fatás (2002), Acemoglu, et al. (2003), Hnatkovska and

*Urban Economist, The Urban Unit, Government of Punjab, ${ }^{* *}$ Senior Visiting Professor, Department of Economics, Government College University, Lahore, Pakistan.

Authors are thankful to anonymous referees of the journal for their valuable suggestions on the paper. 
Loayza (2004), and many others who found similar results. Even so, the relationship between volatility and growth is not always negative. It may either be positive or negative depending on the mechanisms driving the relationship [Imbs (2002)].

A positive link may develop if volatility is associated with occurrence of recession which lead to higher research and development and/or the destruction of least productive firms. Then the higher long-run growth can occur alongside higher volatility [Schumpeter (1939), Shleifer (1986), Hall (1991, Caballero and Hammour (1994), Aghion and Saint-Paul (1998a)]. But, this argument requires deep financial markets, active firm turnover and the ability to conduct the counter-cyclical educational and innovation expenditures. These characteristics are usually associated with developed economies [Hnatkovska and Loayza (2004)]. On the other hand, if recessions are linked with aggravating financial and fiscal constraints, as it is likely to occur in developing countries, these recessions can lead to less human capital development, lower productivity-enhancing expenditures and, thus, lower growth rates [Martin and Rogers (1997), Talvi and Vegh (2000)]. Moreover, to avert the economic recessions, governments may adopt policies such as labor-market restrictions, which make firms less flexible and less willing to innovate, thus, the negative link between volatility and long-run growth may further be deepened [Hnatkovska and Loayza (2004)].

Therefore, the study of fluctuations and growth is more important for developing countries and there is a need to study this volatility-growth relationship in a special context of developing countries. The present study focuses on analyzing the relationship between short-run GDP fluctuations and long-term growth in five selected South Asian countries (SSAC) including Bangladesh, India, Nepal, Pakistan and Sri Lanka for the period of 1980-2010. The paper is organized as follows - Section-II reviews the available existing literature followed by Section III which presents the theoretical framework. Section IV provides the data and methodology whereas Section V gives results and analysis. Finally, Section VI concludes the paper and gives policy recommendations.

\section{Review of Literature}

The study of the relationship between GDP fluctuations and economic growth got much attention after the seminal work of Ramey and Ramey (1995) that challenged the typical view of a dichotomy in the literature of growth and business fluctuations in macroeconomics. The study found that countries with higher volatility have lower growth. However, this link is not always negative as it could either be positive or negative as pointed out by Imbs (2002) who says that the link between growth and volatility depends on the mechanisms driving the relationship. ${ }^{1}$

${ }^{1}$ The Summary of Empirical Literature reviewed with explanation and justification is given in Table A-1 of the Appendix. 


\section{Literature on Negative Growth-Volatility Link}

On the one hand, this relationship might be negative as in a sample of 92 countries and in another sample of 24 OECD countries Ramey and Ramey (1995) found that countries with higher volatility have lower growth. The addition of standard control variables further strengthens this negative relationship. Turnovsky and Chattopadhyay (1998) found that government expenditure volatility terms of trade volatility and monetary volatility have strong negative effects on the equilibrium growth rate. Martin and Rogers (2000) found that countries and regions having higher volatile growth and unemployment rates have lower growth rates. Caballero (2001) showed that the worsening impact of volatility and uncertainty on economic growth is due to the country's structural characteristics. Fatás (2002) concluded that business cycles cannot be regarded as the temporary deviations from a longterm trend and found that countries with more volatile fluctuations display lower long-term growth rates.

Hnatkovska and Loayza (2004) found that macroeconomic (GDP) volatility and long-run economic growth rate are negatively related and this negative relationship actually reflects the harmful effect of volatility on growth. Döpke (2004) found that a positive business cycle shock has a small negative impact on long-run productivity. Fatás and Mihov (2005) found that policy-volatility has a strong and direct negative impact on economic growth. Kose, et al. (2005) highlighted that generally there is a negative relationship between volatility and growth but the nature of this relationship keeps on changing over time, across different country-groups. Siegler (2005) found that there is a robust negative partial correlation between volatility and growth, after controlling other factors related to economic growth. Tochkov and Tochkov (2009) pointed out that provinces in South Korea have higher volatility had lower growth, but this is largely due to common shocks across all provinces.

\section{Literature on Positive Growth-Volatility Link}

The relationship between GDP fluctuations and long-term growth may be positive on the other hand, for instance, Aghion and Saint-Paul (1998a) found that the productivity improvements will be counter-cyclical if productivity growth is costly in terms of the current production. While, the productivity improvements will be pro-cyclical if the cost of productivity improvements is independent of current production. Similarly, Dejuan and Gurr (2004) also found a weak positive relationship between volatility and growth. Comin and Mulani (2007) presented an endogenous growth model and found that as market shares of firms become less persistent, the allocation of resources from the development of general innovations shift to the development of R\&D innovations. This results in an increase in R\&D and firmlevel volatility but there is a decline in aggregate volatility. 


\section{Literature on Mixed Growth-Volatility Link}

Despite the studies (quoted above) which show both the negative and positive link between growth and fluctuations, some of the researchers find mixed results. Kroft and Lloyd-Ellis (2002) found that the majority of the negative relationship comes from the interaction between growth and business cycle movements. The correlation of economic growth with high-frequency volatility was ambiguous or even positive.

Herrero and Vilarrubia (2005) found that a low or moderate level of volatility can actually enhance the economic growth, whereas very high volatility is definitely detrimental to the economic growth. These results showed the existence of a 'Laffer Curve' type relationship between volatility and growth. Imbs (2006) found that, at the sectoral level the growth and volatility links positively; whereas, for aggregated level, the same data-set supported the well-known negative correlation between the aggregate growth and aggregate volatility.

\section{Theoretical Framework}

After a review of the existing available literature, there seems an undisputed view that GDP volatility is related to long-run growth in some way. However, there is neither a theoretical agreement nor reliable empirical evidence that may guide us to consider that the relationship is negative, positive or nonexistent [Edwards and Yang (2009)]. For example, Imbs (2002) says that links between fluctuations and growth might be positive or negative, depending on the mechanisms driving this relationship.

Theoretically, on the one hand, links between GDP fluctuations and long-run growth may be positive, for instance, Edwards and Yang (2009) pointed-out the three different channels suggesting a positive link between GDP volatility and growth. A diagrammatic representation of this positive link between growth and fluctuations is shown in Figure 1.

Firstly, this positive link can be drawn through the channel of consumers' choice between saving and consumption under the increased uncertainty (volatility) about future income. An increase in volatility and uncertainty makes the consumer more inclined to save which results in increased investment and thus higher output growth [Sandmo (1970, Mirman (1971)]. Secondly, according to Edwards and Yang (2009) the positive volatility-growth links can be derived through channel of agents' choice between high-expected-return technologies and or low-expected-return technologies [Black (1987)]. Under this scenario, if agents jointly choose the riskier technologies in a volatile environment, then the growth should be higher in subsequent periods. Thirdly, as pointed out by Edwards and Yang (2009) and Hnatkovska and Loayza (2004) another possible mechanism for a positive relationship is associated with the concept of creative destruction. If these 


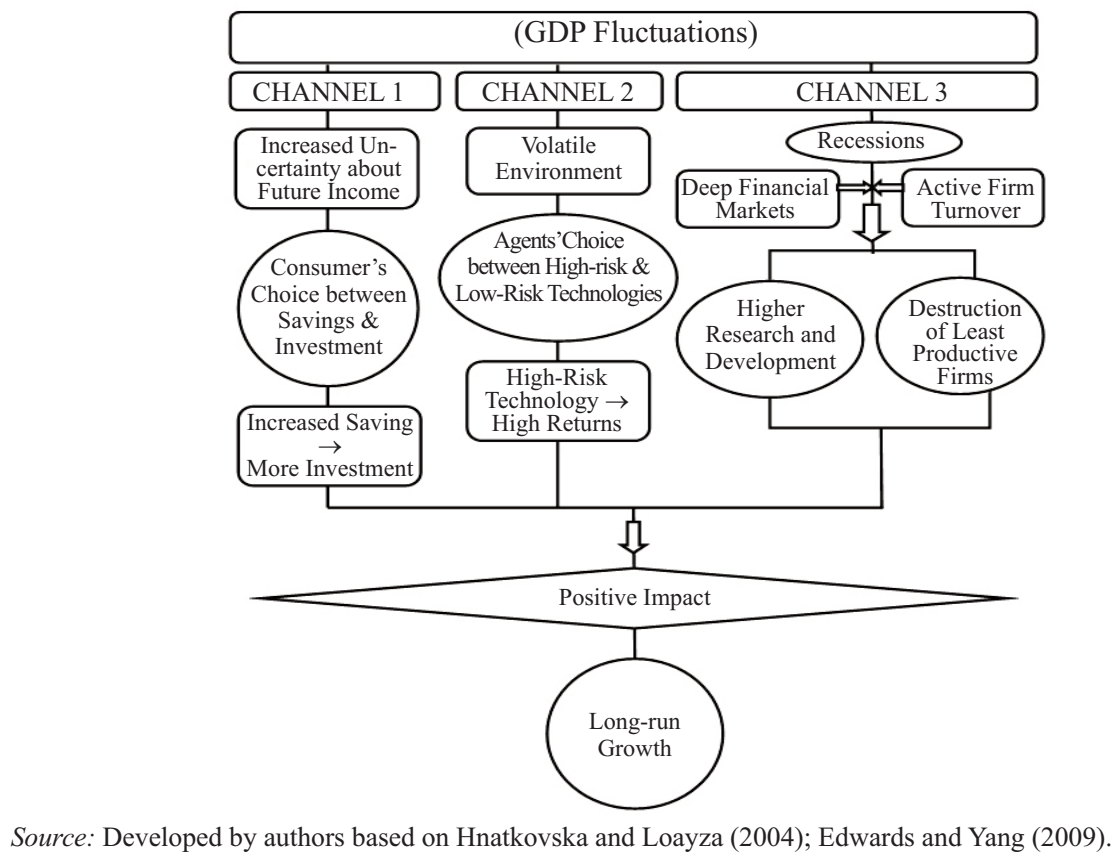

\section{FIGURE 1}

Positive Link between Fluctuations and Growth

fluctuations are linked with the occurrence of recessions and these recessions lead to higher research and development along with the destruction of least productive firms, then higher long-run growth can occur alongside higher volatility [Aghion and Saint-Paul (1998a), (1998b)]. However, this can happen usually for developed countries having deep financial markets, active firm turnover, and the ability to conduct the counter-cyclical educational and innovation expenditures [Hnatkovska and Loayza, (2004)].

On the other hand, the theoretical work has also presented the possibility of a negative link between growth and GDP volatility. Hnatkovska and Loayza (2004) and Edwards and Yang (2009) have discussed some scenarios to show the negative growth-volatility link. A diagrammatic representation of this negative link between growth and fluctuations is shown in Figure 2.

i) As Edwards and Yang (2009) highlight that negative link can establish when investment projects are economically irreversible and firms under increased uncertainty may opt to defer their decisions to invest. This type of waiting-for-better-information behaviour might result in a lower growth rate [Bernanke 1983), Pindyck (1991)].

ii) Edwards and Yang (2009) has pointed-out, another scenario, that in general equilibrium model of Ramey and Ramey (1991) when firms are in a pre-com- 

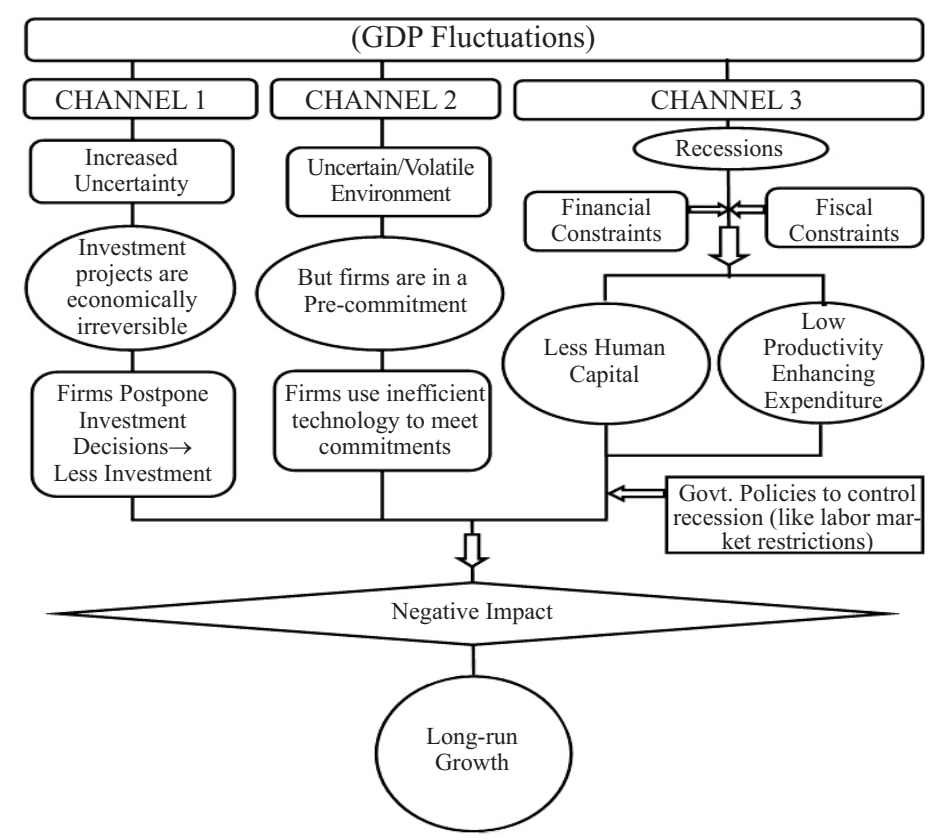

Source: Elaborated by authors based on Hnatkovska and Loayza (2004), Edwards and Yang (2009).

\section{FIGURE 2}

Negative Link between Fluctuations and Growth

mitment they may use an inefficient production technology to meet their commitments, which can then lead to lower growth.

In addition, Edwards and Yang (2009) derived the negative growth-volatility link through another scenario of labour in a learning-by-doing environment [Martin and Rogers (1997), (2000)]. Under this scenario, in times of recession learning-bydoing opportunities are lost and human capital accumulation is slowed leading to a negative growth-volatility relationship [Edwards and Yang (2009)]. Similarly, this scenario is also explained by Hnatkovska and Loayza (2004) showing that a negative link between fluctuations and growth might exist, more likely in case of developing countries which are facing deteriorating financial and fiscal constraints. In such cases, recessions can lead to less human capital development, lower productivity-enhancing expenditures and thus smaller growth rates [Martin and Rogers (1997), Talvi and Vegh (2000)]. Moreover, managing these economic recessions could prompt governments to adopt policies, like labor-market restrictions that make firms less flexible and less innovative, thus further deepening a negative link between volatility and long-run growth [Hnatkovska and Loayza (2004)]. 


\section{Data and Methodology}

\section{Research Hypotheses}

Based on the literature reviewed and the theoretical framework given above, this study intends to test the following hypothesis:

Hypothesis - I: There exists a long-run co-integrating relationship between GDP fluctuations and GDP Growth in the SSAC.

Hypothesis - II: There exists a negative link between GDP fluctuations and GDP Growth in the SSAC.

\section{Data Description}

The annual data on GDP per capita, GDP per capita growth rate for the period 1980-2010 for SSAC is taken from the world development indicators World Bank (2012). The volatility or fluctuation in GDP is measured using five-years moving standard deviation of per capita GDP from the trend, while the long-run growth is measured by five-years moving average of per capita GDP growth rate as most of the cross-section studies uses mean per capita growth rate as proxy of long-run growth. The data of all the control variables including financial development (FINDEV), Investment (INVT) proxied by gross fixed capital formation as percentage of GDP, Government Size (GOVT) proxied by share of government expenditures on final consumption as percentage of GDP, Openness (OPEN) proxied by volume of trade (sum of imports and exports) as percentage of GDP, Population growth rate (POPGR) and initial GDP ${ }^{2}$ (IGDPP) is also taken from the World Bank (2012). ${ }^{3}$

\section{Measurement of GDP Fluctuations}

Since, 'GDP fluctuations' or 'volatility' is the core variable in the present study, therefore the first step before empirical analysis is to measure the GDP fluctuations. Most of the literature follows the standard deviation of GDP growth rate (or per capita growth rate) as a measure of GDP fluctuations in the cross-section studies or panel studies, and the five-years moving standard deviation in time-series studies. But, standard deviation may be an unsatisfactory proxy of volatility [Pritchett (1998) and Breen and García-Peñalosa (1999)]. ${ }^{4}$

2 Initial GDP per capita is measured by natural logarithm of ten years' rolling back window of GDP per capita (GDPP), i.e., the current year initial GDP per capita is ten years back GDP per capita as used by Khan (2010).

3 Detailed variable description along with sources of data has been given in Table A-2, Appendix.

4 Breen and García-Peñalosa, 1999, explains it with an example of two countries with the following growth patterns: country A has annual growth rates of $4,2,4,2,4$, and 2 (per cent), while country B has 4, 4, 4, 2, 2, and 2 (per cent). Both countries will have the same standard deviation (i.e., 1.095) but obviously, country A has the higher level of volatility than B. 
Among other alternatives, ARCH/GARCH model can be used for time-series analysis but these are mostly suitable for financial variables and other variables (i.e., exchange rate, prices, etc.) where high frequency data is available. Lensink, et al. (1999) pointed out that to measure volatility the application of GARCH models requires high-frequency observations and long time series; moreover, the GARCH-type models of volatility are also criticized due to the possible misspecification of the conditional mean equation. Therefore, for measuring GDP fluctuation the current study uses standard deviation from trends (SDFT) which is closer to the definition of GDP fluctuations ${ }^{5}$ because it shows the deviation of growth rate of GDP from its trend values. The formula for SDFT can be written by replacing Mean of GDPPCg $g_{t}$ with Trend value of GDPPCg $_{t}$ year $t\left(\mathrm{GDPPCgT}_{t}\right)$ in the simple standard deviation formula [Equation (1)]:

$$
\mathrm{SDFT}=\sqrt{\frac{1}{n-1} \sum_{t-1}^{n}\left(G D P P C g_{t}-G D P P C g T_{t}\right)^{2}}
$$

where, GDPPCg $g_{t}$ is GDP per capita growth rate in year $t, \mathrm{GDPPCgT}_{t}$ is the trend value of GDP per capita growth at time $t, n$ is the total number of years. To measure SDFT using the above formula, first of all the series of GDP per capita growth rate of each country (individually) has been decomposed into trend and cyclical components using the Hodrick-Prescott (HP) filter [Hodrick and Prescott (1997)] with a smoothing parameter set at 6.25 [as suggested by Ravn and Uhlig (2002) for annual data]. Then the standard deviation of cyclical component is calculated to get the SDFT. Hodrick and Prescott (1997) originally found the value of smoothing parameter $(\lambda)$ as 1600 for US quarterly data. Rand and Tarp (2002) found that business cycles in developing countries are significantly shorter in duration than the cycles in developed countries. Therefore, the present study uses the choice of $\lambda=6.25$ suggested by Ravn and Uhlig (2002) for annual data. The standard deviation of cyclical component gives the same value of SDFT [as in the formula given in Equation (1)] which can be proved as under:

$$
\text { Cyclical Component of } G D P P C g_{t}\left(C y c_{t}\right)=G D P P C g_{t}-G D P P C g T_{t}
$$

Therefore, the SD of $\mathrm{Cyc}_{\mathrm{t}}$ will be;

$$
\begin{gathered}
\text { SD of } C y c_{t}=\sqrt{\frac{1}{n-1} \sum_{t-1}^{n}\left(C y c_{t}-\overline{C y c}\right)^{2}} \\
\text { But, } \overline{C y c}_{t}=0 \text { as } \sum\left(G D P P C g_{t}-G D P P C g T_{t}\right)=0
\end{gathered}
$$

5 GDP Fluctuation refers to the deviations of GDP growth rate (or per capita growth rate) around its trend or potential level. 
Thus, after putting these values of $C y c_{t}$ and $\overline{C y c}$ from Equation (2) and (4), respectively, in Equation (3):

$$
\mathrm{SD} \text { of } C y c_{t}=\sqrt{\frac{1}{n-1} \sum_{t-1}^{n}\left(G D P P C g_{t}-G D P P C g T_{t}\right)^{2}}
$$

Hence, it is proved that,

$$
\mathrm{SD} \text { of } C y c=\mathrm{SDFT}
$$

The SDFT (SD of Cyc) provides a measure of volatility in GDP growth during the whole period of 1980-2010. To compare the decade-wise trends of GDP fluctuations in the SSAC, this study also calculates the SDFT for the sub-periods of ten years. The above calculation (of SDFT or SD of Cyc) gives an aggregate measure of volatility, but for the empirical analysis the annual (year-by-year) time-series data on GDP fluctuation is needed. For this purpose the five-years moving SDFT is used, this provides a series of GDP fluctuations for an adjusted period of 19822008. Now, for five-years moving SDFT Equation (1) becomes as under:

$$
\text { Five years moving } S D F T_{t}=\sqrt{\frac{1}{5-1} \sum_{\mathrm{t}-2}^{t+2}\left(G D P P C g_{t}-G D P P C g T_{t}\right)^{2}}
$$

An annual series of GDP fluctuations has been generated by using the formula [Equation (6)] and the time-period is adjusted to 1982 to 2008 from 1980 to 2010, due to using the five-years moving method.

\section{Econometric Methodology}

Most of the existing studies having micro-panel data used the country average simple arithmetic mean and standard deviation of GDP per capita growth rate of the time-period under study as a proxy of long-run growth and volatility, respectively. While, some panel-data studies used the country-average for the sub-periods by dividing the time-period in decades or even smaller sub-periods. Since this study is also interested in testing the consistency of GDP fluctuations and growth relationship over time, this method of country-average is not suitable in this case. Due to small country-sample, the present study uses the five-year moving average. The study also uses five-years moving average of GDP per capita growth rate as a proxy of long-run growth and five-years moving standards deviation from trend of GDP per capita growth rate which is used to measure the GDP fluctuations.

The existing panel data studies, until very recently, ignored the issue of non-stationarity in the panel-data [Asteriou (2006)]. Similarly, the existing panel data studies on GDP volatility and growth, seems to ignore the issue of non-stationarity in the panel-data. However, in a macro-panel model (with small $\mathrm{N}$ and large $\mathrm{T}$ ), like present study, the existence of non-stationarity is more likely. Therefore, this study employs 
the panel cointegration framework. But, before proceeding to the cointegration analysis, first the order of integration is to be checked, by applying the unit root tests. Along with the unit root analysis another recently developed concept of the cross sectional dependence is also gaining lot of attraction in the recent non-stationary panel literature. Therefore, the current study employs the Cross Sectional Dependence (CD) test by Pesaran (2004) before applying the panel unit root test.

\section{a) Cross Sectional Dependence Test}

Pesaran (2004) suggests a simple test for testing the cross-sectional dependence (CD) which can be applied to the variety of panel-data models including stationary and non-stationary dynamic heterogeneous panels. This CD test is based on the average of pair-wise correlation coefficients of OLS residuals from the individual regressions in the panel [Baltagi (2005), p. 247]:

\section{b) Panel Unit Root Test}

$$
C D=\sqrt{\frac{2 T}{N(N-1)}\left(\sum_{i=1}^{N-1} \sum_{j=i+1}^{N} \hat{\rho}_{i j}\right)}
$$

The first step in determining the potential cointegrated relationship is to test whether the variables of interest are stationary or non-stationary. There are many tests available for testing the unit root in panel data like Breitung (2000), Hadri (2000), Levin, et al. (2002) test (known as LLC test), and Im, et al. (2003) test (known as IPS test), etc. But all these tests assumes cross sectional independence. As mentioned earlier it is more likely that our data may have cross-sectional dependence, therefore, none of these above-mentioned tests can be used.

Accordingly, the current study employs the Breitung and Das (2005) panel unit root test. The main advantage of this test is that it can also be applied in the presence of cross-sectional dependence. In case of cross-sectional dependence the robust value of lambda is calculated to account for the cross-sectional dependence otherwise in case of cross-sectional independence the simple value of lambda is calculated [Breitung and Das (2005)].

\section{c) Panel Cointegration Test}

After confirming the order of integration of variables of interest, and if the variables are non-stationary, the next step is to check for cointegration, because the use of traditional OLS may give spurious results in presence of the unit root. Therefore, the current study uses the panel cointegration technique. For the panel cointegration test, the current study employs Pedroni [(1997), (1999) and (2004a)] panel cointegration tests. The main advantage of using Pedroni panel cointegration test is that 
it accounts for cross-section dependence, if common time dummies added as Banerjee and Lluís (2006) pointed out that most panel data tests (including Pedroni) assume cross-section independence, except for common time effects. Therefore, the addition of common time effects (common time dummies) may account for the problem of cross-sectional dependence.

The panel regression model to analyze the long-run cointegrating relationship between growth and GDP fluctuations for Pedroni panel cointegration test, can be represented as under:

$$
L G R_{i . t}=\alpha_{i}+\delta_{t} \sum_{m=1}^{M} \beta_{m i} F L U C_{m i, t}+e_{i, t}
$$

where LGR $=$ Long-run growth rate, and FLUC $=$ GDP fluctuations.

Using the above equation, the null of no cointegration is tested through seven test statistics developed by Pedroni (1999). The first four statistics (Panel-v, Panel$\rho$ and Panel-t (PP and ADF)) are based on pooling the residuals along the within dimension of the panel. The rest of three statistics (Group- $\rho$ and Group-t (PP and ADF)) are based on pooling the residuals along the between dimension of the panel [Pedroni (1999)].

\section{d) Panel Estimation using Group Mean FMOLS Approach}

The panel cointegration test provides information about the long-run equilibrium relationship among the variables but they do not estimate the cointegrating vectors. For this purpose, the present study uses the group mean (panel) fully modified ordinary least squares (GM-FMOLS) developed by Pedroni [(2001a), (2001b), (2004b)] which is an extension of time-series fully modified OLS (FMOLS) by Phillips and Hansen (1990).

The main advantage of using GM-FMOLS estimator is that it not only gives consistent estimates of $\beta$ parameters in relatively small samples, but it also controls for the likely endogeneity of the regressors and serial correlation [Ramirez (2010), AlYousef (2013)]. This technique also control for the likely cross-sectional dependence by including common time dummies in the model [Pedroni (2001a), Lee (2007)]. Another method which allow estimation in the presence of cross-sectional dependence is the Pesaran (2006) CCEMG estimator, but all the mean group family estimators are variants of mean group estimators and according to Pesaran, et al. (1999), "mean group estimator is asymptotically normal for large $\mathrm{N}$ and large $\mathrm{T}$... it is unlikely to be a good estimator when either $\mathrm{T}$ or $\mathrm{N}$ is small". Therefore, this study prefers GM-FMOLS over mean group family. Moreover, Tsangarides, et al. (2007) pointed out that GM-FMOLS estimators have satisfactory size and power properties even for small panels, as long as $\mathrm{T}$ is larger than $\mathrm{N}$, and in the presence 
of homogeneous cointegrating vector mean-group, estimators have better small sample performance than within the group estimators. Tsangarides, et al. (2007) further highlighted the PMG estimator and imposes long-run homogeneity which can also produce inconsistent estimates of the average values of parameters, if the assumption of homogeneity is violated in practice. Therefore, the present study employs the GM-FMOLS with common time dummies to estimate the long-run cointegrating vector.

To model the relationship between GDP fluctuations and long-run growth, this study follows the methodology of Ramey and Ramey (1995), Fatás (2002), and Hnatkovska and Loayza (2004) and construct a simple model, represented as:

$$
L G R_{i . t}=\alpha_{i}+\beta_{i} F L U C_{i . t}+\varepsilon_{i, t}
$$

where, LGR is a long-run growth, FLUC is a GDP Fluctuations, $\alpha$ is an intercept, $\beta_{1}$ is elasticity coefficient (to be measured to examine the relationship between growth and fluctuations) and is expected to be negative for developing countries, as in the case of SSAC, $\varepsilon$ is residual of equation or random error-term; while i represents the country and $t$ represents the time-period (a year, in the case of this study).

Adding control variables in Equation (3) helps to analyze whether the simple link between GDP fluctuations and long-term growth is channelled through regular growth determinants [Hnatkovska and Loayza (2004)]. Therefore, after adding control variables Equation (9) can be represented as:

$$
L G R_{i . t}=\alpha_{i}+\beta_{i} F L U C_{i . t}+\gamma_{i} X_{i . t}+\varepsilon_{i, t}
$$

where, $\mathrm{X}$ represents a set of control variables including IGDPP (natural logarithm of Initial GDP per capita, a proxy of transitional convergence or developmental level of the country), FINDEV is financial development. For cross-country growth analysis these control variables were suggested by Levine and Renelt (1992) and, along with other control variables were also used by Ramey and Ramey (1995), Fatás (2002) and Hnatkovska and Loayza (2004). Along with these variables some other determinants of growth like Investment (INVT), Government Size (GOVT), Trade Openness (OPEN) and Population growth rate (POPGR) are also added as control variables used by [Khan (2010)].

All idiosyncratic (individual country) coefficients $\left(\hat{\beta}_{F M, i}^{*}\right)$ and associated t-statistic for each country $(i)$ are estimated by using Equation (10). The Group Mean (Between-Dimension) panel estimates $\left(\hat{\beta}_{G F M}\right)$ can be calculated by using the following formula [Pedroni (2004b)].

$$
\hat{\beta}_{G F M}=N^{-1} \sum_{t-1}^{N}\left(\sum_{t-1}^{T}\left(P_{i t}-\bar{P}_{i}\right)\right)^{-1} \times\left(\sum_{t-1}^{T}\left(P_{i t}-\bar{P}_{i}\right) s_{i t}^{*}-T \hat{\gamma}_{i}\right)
$$


where,

$$
\begin{gathered}
s_{i t}^{*}=\left(S_{i t}-\bar{S}_{i}\right)-\frac{\hat{\Omega}_{21 i}}{\hat{\Omega}_{22 i}} \Delta p_{i t} \\
\hat{\gamma}_{i}=\hat{\Gamma}_{21 i}+\hat{\Omega}_{21 i}^{\circ}-\frac{\hat{\Omega}_{21 i}}{\hat{\Omega}_{22 i}}\left(\hat{\Gamma}_{22 i}+\hat{\Omega}_{21 i}^{\circ}\right)
\end{gathered}
$$

In Equation (11) expression after the summation over $i$ is similar to the conventional idiosyncratic time-series estimator $\left(\hat{\beta}_{F M, i}^{*}\right)$, therefore, the between dimension panel estimator $\left(\hat{\beta}_{G F M}\right)$ can be simply constructed by,

$$
\hat{\beta}_{G F M, i}^{*}=N^{-1} \sum_{t-1}^{N} \hat{\beta}_{F M, i}^{*}
$$

where, $\hat{\beta}_{F M, i}^{*}$ is the conventional time-series (individual country) FMOLS estimator of ith member of panel. Similarly, related t-statistic for the between dimension panel estimator can be measured by the following formula given by Pedroni (2004b).

$$
\mathrm{t}_{\hat{\beta}_{G F M}^{*}}=N^{-1 / 2} \sum_{t-1}^{N} \mathrm{t}_{\hat{\beta}_{F M, i}^{*}}
$$

where, ${ }^{\mathrm{t}_{\hat{\beta}_{F M i}^{*}}}$ is the conventional time-series (individual country, $i$ ) t-statistic, of $i t h$ member of panel, associated with related $\hat{\beta}_{F M, i}^{*}$. The formula of $t_{\hat{\beta}_{F M, i}^{*}}$ by Pedroni (2004b) is given as:

$$
\mathrm{t}_{\hat{\beta}_{F M, i}^{*}}=\left(\hat{\beta}_{F M, i}^{*}-\beta_{\circ}\right)\left(\hat{\Omega}_{11 i}^{-1} \sum_{t-1}^{T}\left(P_{i t}-\bar{P}_{i}\right)^{2}\right)^{1 / 2}
$$

\section{Results and Analysis}

\section{Cross Sectional Dependence Testing}

The results of CD Test by Pesaran (2004) are given in Table 1 which shows that except the GDP fluctuations (FLUC) and Government Size (GOVT) the null of no cross-sectional independence can be rejected.

All variables except the FLUC and GOVT are found as cross-sectionally dependent variables, whereas, GDP fluctuations (FLUC) and Government Size (GOVT) are found as cross-sectionally independent variables. ${ }^{6}$

\footnotetext{
6 Pesaran (2004) CD Test implemented using XTCD Stata Module by Eberhardt (2011).
} 


\section{Panel Unit Root Testing}

Table 2 depicts the results of Breitung and Das (2005) panel unit root test at level. The value of lambda $(\lambda)$ statistic shows that at level all variables are non-stationary at 5 per cent level of significance. The robust values of lambda $(\lambda)$ are given to account for cross-sectional dependence except the FLUC and GOVT which are the cross-sectionally independent. Similarly, Table 3 shows the results of Breitung and Das (2005) panel unit root test at the first difference.

Results of Breitung and Das (2005) panel unit root test shows that all variables are integrated of order one, i.e., I(1).

\section{TABLE 1}

Cross Sectional Dependence (Growth and GDP Fluctuations)

\begin{tabular}{lcccc}
\hline Variable & CD-test & p-value & Corr & abs (corr) \\
\hline OPEN & 4.740 & 0.000 & 0.289 & 0.375 \\
GOVT & -1.110 & 0.265 & -0.068 & 0.339 \\
FINDEV & 9.860 & 0.000 & 0.600 & 0.600 \\
LGR & 2.950 & 0.003 & 0.180 & 0.321 \\
INVT & 3.530 & 0.000 & 0.215 & 0.275 \\
FLUC & 0.540 & 0.588 & 0.033 & 0.242 \\
POPGR & 10.390 & 0.000 & 0.633 & 0.633 \\
IGDP & 15.770 & 0.000 & 0.960 & 0.960 \\
\hline
\end{tabular}

Notes: Under the null hypothesis of cross-section independence CD N $(0,1)$ Source: Author's Calculation.

TABLE 2

Breitung and Das (2005) Panel Unit Root Test (at Level)

Lambda Statistic (Probability in parenthesis)

\begin{tabular}{cccccccc}
\hline \multicolumn{7}{c}{ Lambda Statistic (Probability in parenthesis) } \\
\hline FINDEV & INVT & FLUC & GOVT & IGDPP & LGR & OPEN & POPGR \\
\hline \multicolumn{7}{c}{ With Intercept Only } \\
\hline 3.2224 & 0.1908 & -0.4644 & -1.0303 & 7.3986 & 0.0082 & 1.3295 & -0.4406 \\
$(0.9994)$ & $(0.5757)$ & $(0.3212)$ & $(0.1514)$ & $(1.0000)$ & $(0.5033)$ & $(0.9082)$ & $(0.3928)$ \\
\hline \multicolumn{7}{c}{ With Intercept and Trend } \\
\hline 3.0679 & -0.0029 & -1.4907 & 0.1809 & 0.6553 & -0.3935 & 1.7235 & -1.5776 \\
$(0.9989)$ & $(0.4988)$ & $(0.0680)$ & $(0.5718)$ & $(0.7439)$ & $(0.3470)$ & $(0.9576)$ & $(0.5730)$ \\
\hline
\end{tabular}

$* *$ and $* * *$ represent the rejection of null hypothesis of no unit root at $5 \% \& 1 \%$ level of significance, respectively. 


\section{Panel Cointegration Testing}

After affirmation of the order of integration of variables, the results of the bivariate Pedroni panel cointegration tests are shown in Table 4. The Pedroni's five panel test statistics (out of the total seven statistics) shows the existence of long-run equilibrium relationship between LGR and FLCU in case of model with intercept and no trend. The results are also same for the model with intercept and trend.

\section{TABLE 3}

Breitung and Das (2005) Panel Unit Rot Test (at $1^{\text {st }}$ Difference)

\begin{tabular}{lccccccc}
\hline \multicolumn{7}{c}{ Lambda Statistic (Probability in parenthesis) } \\
\hline FINDEV & INVT & FLUC & GOVT & IGDPP & LGR & OPEN & POPGR \\
\hline \multicolumn{7}{c}{ With Intercept Only } \\
\hline$-4.9692^{* * *}$ & $-4.7282^{* * *}$ & $-7.4447^{* * *}$ & $-4.9800^{* * *}$ & $-5.496^{* * *}$ & $-3.104^{* * *}$ & $-4.1148^{* * *}$ & $-2.28^{* * *}$ \\
$(0.0000)$ & $(0.0000)$ & $(0.0000)$ & $(0.0000)$ & $(0.0000)$ & $(0.0010)$ & $(0.0000)$ & $(0.0114)$ \\
\hline \multicolumn{7}{c}{ With Intercept and Trend } \\
\hline$-1.6883^{* *}$ & $-5.0905^{* * *}$ & $-6.7141^{* * *}$ & $-2.225^{* *}$ & $-7.211^{* * *}$ & $3.5213^{* * *}$ & $-3.4999^{* * *}$ & $-2.6508^{* * *}$ \\
$(0.0457)$ & $(0.0000)$ & $(0.0000)$ & $(0.0131)$ & $(0.0000)$ & $(0.0002)$ & $(0.0002)$ & $(0.0040)$ \\
\hline
\end{tabular}

** and $* * *$ represent the rejection of null hypothesis of no unit root at $5 \%$ and $1 \%$ level of significance respectively.

TABLE 4

GDP Fluctuations and Long-run Growth - Panel Cointegration Test for SSAC

\begin{tabular}{lcccc}
\hline \multirow{2}{*}{ Test Statistics } & \multicolumn{2}{c}{ With Intercept and No Trend+ } & \multicolumn{2}{c}{ With Intercept and Trend+ } \\
\cline { 2 - 5 } & Un-weighted & Weighted++ & Un-weighted & Weighted++ \\
\hline panel v-stat & -0.6275 & -0.4235 & -0.1411 & -0.353 \\
panel rho-stat & 1.3593 & 1.3926 & 1.7899 & 1.9396 \\
panel pp-stat & $-1.5277^{*}$ & $-1.6665^{*}$ & $-2.9384^{* * *}$ & $-2.3183^{* * *}$ \\
panel adf-stat & $1.5016^{*}$ & 1.3018 & $2.5776^{* * *}$ & $2.1030^{* *}$ \\
group rho-stat & $2.1846^{* * *}$ & - & $2.6625^{* * *}$ & - \\
group pp-stat & $-1.9891^{* *}$ & - & $-2.3614^{* * *}$ & - \\
group adf-stat & $1.8357^{*}$ & - & $2.2072^{* * *}$ & - \\
\hline
\end{tabular}

Note: Null hypothesis: no cointegration, + common time dummy included to account for cross sectional dependence, ++ Panel stats are weighted by long run variances, *** and ** represent the rejection of null hypothesis of no unit root at $10 \%, 5 \%$ and $1 \%$ level of significance, respectively. 


\section{Group Mean FMOLS Results and Discussions}

The long-run GM-FMOLS, i.e., Pedroni panel (group-mean) FMOLS estimates are presented in Table 5..$^{7}$ The results of the GM-FMOLS estimations show a negative and highly significant relationship between the long-run growth rate and GDP fluctuations in SSAC and the Investment, Openness, Initial GDP has positive and significant relationship with long-run growth rate in SSAC. The investment and Openness has positive link with growth which is according to the theory [Khan (2010), Ramey and Ramey (1995) and many others]. In light of both the hypotheses [mentioned in Section IV(1)] are accepted hereby as there exists a long-run co-integrating relationship, the link of which is negative as well, in the SSAC.

Most of the literature shows that links between the initial GDP per capita is negative, however, some studies found positive link as Tabassum and Majeed (2008) found positive relation between these variables in the South and East Asia.

TABLE 5

Group Mean Fully Modified OLS (GM-FMOLS) Results

\begin{tabular}{|c|c|c|c|}
\hline \multicolumn{4}{|c|}{ Dependent Variable: Long-run Growth (LGR) } \\
\hline Variable & & Coefficient & $\mathrm{t}-$ Statistics \\
\hline$\overline{\text { FLUC }}$ & & -0.72417 & $-10.6377^{* * *}$ \\
\hline INVT & & 0.140064 & $7.671727^{* * *}$ \\
\hline FINDEV & & 0.009261 & 1.290727 \\
\hline GOVT & & -0.31143 & $-9.10337^{* * *}$ \\
\hline OPEN & & 0.03243 & $1.865097^{* *}$ \\
\hline IGDPP & & 5.69959 & $3.292461^{* * *}$ \\
\hline POPGR & & -0.8324 & $-5.01019^{* * *}$ \\
\hline Constant & & 0.53876 & -0.32469 \\
\hline \multicolumn{4}{|l|}{ Diagnostic Testing } \\
\hline Residual Stationarity & $\mathrm{I}(0)$ & CD Test for Residual & $\begin{array}{c}-0.6 \\
(0.546)\end{array}$ \\
\hline F Test & $\begin{array}{c}166.093 \\
(0.000)\end{array}$ & RMSE & 0.8209 \\
\hline
\end{tabular}

$*, * *$ and $* * *$ represents $10 \%, 5 \%$ and $1 \%$ significance level, respectively.

7 The GM-FMOLS model is estimated using RATS code (PANELFM) by Doan (2012). 
Government size and population growth have negative and significant relationship with long run growth in SSAC which is according to the literature [Khan (2010), Ramey and Ramey (1995)]; while the financial development (FINDEV) has positive but insignificant relationship with growth which is also similar to the literature as the relationship is positive in the long-run [Khan (2010)].

The post estimation diagnostic tests are also shown in Table 5. These tests show that the F-test is significant and residuals are stationery. CD Test for residuals shows that they are cross-sectionally independent which shows that adding common time dummies resolve the issue of cross section dependence. The results of GM-FMOLS estimation show that relationship between the long-run growth and GDP fluctuations is significant and negative. The results are similar to those of Ramey and Ramey (1995), Fatás (2002), Acemoglu, et al. (2003), Hnatkovska and Loayza (2004) and many others found similar results.

\section{Conclusion and Policy Implications}

This study investigates the impact of GDP fluctuations on long-run economic growth by employing the modern panel approach in a panel of five selected South Asian countries (SSAC) over the period of 1980-2010. For this purpose, modern non-stationary panel techniques such as cross section dependence test, unit root test under the cross sectional dependence, panel cointegration and Group Mean Fully Modified OLS (GM-FMOLS) estimation are applied.

The study finds presence of cross-section dependence and non-stationarity among variable. The Peroni panel cointegration shows that there exists a long-run cointegrating relationship between GDP fluctuations and long-run growth in the SSAC; GM-FMOLS estimates show that this link is negative. Thus, the results indicate that GDP fluctuations have a significant negative impact on long-run growth in the SSAC. The results are similar to those of Ramey and Ramey (1995), Fatás (2002), Acemoglu, et al. (2003), Hnatkovska and Loayza (2004) and many others who found similar results. The other determinants of the growth were added as control variables and were found significant and as per literature and theory.

These findings have serious policy implications for developing countries, generally and for South Asia, particularly. The significant negative impact of GDP fluctuations on long-run growth suggests that these fluctuations and volatility of GDP may be detrimental to long-run growth in developing countries. Therefore, the governments shouldn't rely only on growth-oriented policies but should equally focus on managing the volatility of GDP to achieve sustained and stable growth. Therefore, there is a need to identify the underlying sources and determinants of GDP fluctuations in order to devise a policy mechanism to curtail and manage these fluctuations. As, Caballero (2001) shows that the worsening impact of volatility and uncertainty on economic growth is due to the country's structural characteristics 
like poor financial development, procyclical fiscal policy and deficient rule of law usually goes together with large public indebtedness. Thus, serious efforts are needed to improve country's structural characteristics and to control other sources of volatility to manage the GDP fluctuations.

The Urban Unit, Government of Punjab, and

The Government College University, Lahore, Pakistan.

\section{Bibliography}

Acemoglu, D., S. Johnson, J. Robinson and Y. Thaicharoen, 2003, Institutional causes, macroeconomic symptoms: Volatility, crises and growth, Journal of Monetary Economics, 50: 49-123.

Aghion, P., and G. Saint-Paul, 1998a, Virtues of bad times: Interaction between productivity growth and economic fluctuations, Macroeconomic Dynamics, 2: 322-344.

Aghion, P., and G. Saint-Paul,1998b, Uncovering some causal relationships between productivity growth and the structure of economic fluctuations: A tentative survey, Labour, 12: 279-303.

AlYousef, N., 2013, Demand for oil products in OPEC countries: A panel cointegration analysis, International Journal of Energy Economics and Policy, 3(2): 168-177.

Asteriou, D., 2006, Applied econometrics: A modern approach using e-views and microfit, New York: Palgrave Macmillan Press.

Baltagi, B.H., 2005, Econometric analysis of panel data, 3rd edition, New York: John Wiley \& Sons, Ltd.

Banerjee, A., and J. Luís, 2006, Cointegration in panel data with breaks and crosssection dependence, Working paper series 591, European Central Bank.

Bernanke, B.S., 1983, Irreversibility, uncertainty, and cyclical investment, Quarterly Journal of Economics, 98: 85-106.

Black, F., 1987, Business cycles, and equilibrium, New York: Basil Blackwell.

Breen, R., and C. García-Peñalosa, 1999, Income inequality and macroeconomic volatility: An empirical investigation, Economics papers 1999-w20, Economics group, Nuffield College, University of Oxford.

Breitung, J., 2000, The local power of some unit root tests for panel data, in: Advances Econometrics, Nonstationary panels, Panel cointegration, and Dynamic panels, B.H. Baltagi, (ed.,) 15: 161-178. Amsterdam: JAI press. 
Breitung, J., and S. Das, 2005, Panel unit root tests under cross-sectional dependence, Statistica Neerlandica, 59: 414-433.

Caballero, R.J., 2001, Macroeconomic volatility in Latin America: A view and three case studies, Estudios de Economía, 28(1): 5-52.

Caballero, R J., and M.L. Hammour, 1994, The cleansing effect of recessions, The American Economic Review, 84(5): 1350-1368.

Comin, D., and S. Mulani, 2007, A theory of growth and volatility at the aggregate and firm level, Proceedings, Federal Reserve Bank of San Francisco.

Dejuan, J., and S. Gurr, 2004, On the link between volatility and growth: Evidence from Canadian provinces, Applied Economics Letters, 11: 279-282.

Doan, T., 2012, PANELFM: RATS procedure to perform panel data group mean FMOLS, Statistical software components, RTS00151, Boston College, Department of Economics.

Döpke, J., 2004, The effects of business cycles on growth: Time series evidence for the G7-countries using survey-based measures of the business cycle, CESifo Economic Studies, 50(2): 333-349.

Eberhardt, M., 2011, XTCD: Stata module to investing at variable/residual crosssection dependence, Statistical software components S457237, Boston College, Department of Economics.

Edwards, J.A., and B. Yang, 2009, An empirical refinement of the relationship between growth and volatility, Applied Economics, 41(11): 1331-1343.

Fatás, A., 2002, The effects of business cycles on growth, Central Bank of Chile, Working paper 156.

Fatás, A., and I. Mihov, 2005, Policy volatility, institutions and economic growth, CEPR discussion paper 5388, Centre for Economic Policy Research, London: UK.

Hadri, K, 2000, Testing for stationarity in heterogeneous panel data, Econometrics Journal, 3: 148-161.

Hall, R.E., 1991, Labor demand, labor supply, and employment volatility, NBER Macroeconomics Annual, : 17-46.

Herrero, A.G., and J. Vilarrubia, 2005, The Laffer curve of macroeconomic volatility and growth: Can it be explained by the different nature of crises? SSRN working paper series, Available at http://ssrn.com/abstract $=887100$.

Hnatkovska, V., and N. Loayza, 2004, Volatility and growth, Policy Research working paper series 3184, Washington DC: The World Bank [Published in Aizenmann, J. and Pinto, B. (eds.,) (2005)]. Managing Economic Volatility and Crises, Cambridge: United Kingdom, Cambridge University Press.

Hodrick, R., and E. Prescott, 1997, Post-war US business cycle: An empirical investigation. Journal of Money, Credit and Banking, 29(1): 1-16.

Im, K.S., M.H. Pesaran, and Y. Shin, 2003, Testing for unit roots in heterogeneous panels, Journal of Econometrics, 115: 53-74. 
Imbs, J., 2002, Why the link between volatility and growth is both positive and negative, CEPR discussion papers 3561.

Imbs, J.M., 2006, Growth and volatility, Swiss Finance Institute research paper 06-9.

Khan, M.N., 2010, Decomposition of the effects of financial development on economic growth: A panel cointegration analysis, Unpublished masters thesis, Department of Economics, Stockholm University.

Kose, M.A., E.S. Prasad, and M.E. Terrones, 2005, Growth and volatility in an era of globalization, IMF staff papers, 52 (Special Issue).

Kroft, K., and H. Lloyd-Ellis, 2002, Further cross-country evidence on the link between growth, volatility and business cycles, Queens University working paper.

Lee, G., 2007, Long run equilibrium relationship between inward FDI and productivity, Journal of Economic Development, 32(2): 183-192.

Lee, J., 2010, The link between output growth and volatility: Evidence from a GARCH model with panel data, Economic Letters, 106: 143-145.

Lensink, R., H. Bo, and E. Sterken, 1999, Does uncertainty affect economic growth? An empirical analysis, Review of World Economics (Weltwirtschaftliches Archiv), 135(3): 379-396.

Levin, A., C.-F. Lin, and C.-S.J. Chu, 2002, Unit root tests in panel data: Asymptotic and finite-sample properties, Journal of Econometrics, 108: 1-24.

Levine, R., and D. Renelt,1992, A sensitivity analysis of cross-country growth regressions, American Economic Review, 82(4)L 942-63.

Martin, P., and C.A. Rogers, 1997, Stabilization policy, learning by doing, and economic growth, Oxford Economic Papers.

Martin, P., and C.A. Rogers, 2000, Long-term growth and short-term economic instability, European Economic Review, 44(2): 359-381.

Mirman, L.J., 1971, Uncertainty and optimal consumption decisions, Econometrica, 39: $179-85$.

Pedroni, P., 1997, Panel cointegration: Asymptotic and finite sample properties of pooled time series tests with an application to the PPP hypothesis: New results, working paper, Indiana University.

Pedroni, P., 1999, Critical values for cointegration tests in heterogeneous panels with multiple regressors, Oxford Bulletin of Economics and Statistics, 61: 653-70.

Pedroni, P., 2001a, Fully modified OLS for heterogeneous cointegrated panels, Advances in Econometrics, 15: 93-130.

Pedroni, P., 2001b, Purchasing power parity tests in cointegrated panels, The Review of Economics and Statistics, 83: 727-31.

Pedroni, P., 2004a, Panel cointegration: Asymptotic and finite sample properties of pooled time series tests with an application to the PPP hypothesis, Econometric Theory, 20: 597-625.

Pedroni, P., 2004b, Purchasing power parity tests in cointegrated panels, The Review of Economics and Statistics, 83(4): 727-731. 
Pesaran, M.H., Y. Shin, and R. Smith, 1999, Pooled mean group estimation of dynamic heterogeneous panels, Journal of the American Statistical Association, 94, 621-634.

Pesaran, M.H., 2004, General diagnostic tests for cross section dependence in panels, CESifo working paper series 1229, Munich: CESifo Group.

Pesaran, M.H., 2006, Estimation and inference in large heterogeneous panels with a multifactor error structure, Econometrica, 74(4):.967-1012.

Pesaran, M.H., and R.P. Smith, 1995, Estimating long-run relationships from dynamic heterogeneous panels, Journal of Econometrics, 68(1): 79-113.

Phillips, P., and B. Hansen, 1990, Statistical inference in instrumental variables regression with I(1) processes, Review of Economic Studies, 57: 99-125.

Pindyck, R.S., 1991, Irreversibility, uncertainty and investment, Journal of Economic Literature, 29: 1110-1148.

Pritchett, L., 1998, Patterns of economic growth: Hills, plateaus, mountains, and plains, Miemo: World Bank.

Ramey, G., and Y.A. Ramey,1991, Technology commitment and the cost of economic fluctuations, NBER working paper 3755.

Ramey, G., and V.A. Ramey, 1995, Cross-country evidence on the link between volatility and growth, American Economic Review, 85 (5): 1138-1150.

Ramirez, M. D., 2010, Are foreign and public capital productive in the Mexican case? A panel unit root and panel cointegration analysis, Eastern Economic Journal, 36(1): 70-87.

Rand, J., and E.F. Tarp, 2002, Business cycles in developing countries: Are they different? World Development, 30(12): 2071-2088.

Ravn, M.O., and H. Uhlig, 2002, On adjusting the Hodrick-Prescott filter for the frequency of observations, The Review of Economics and Statistics, 84(2): 371-375.

Sandmo, A., 1970, The effect of uncertainty on saving decisions, Review of Economic Studies, 37: 353-60.

Schumpeter, J.A., 1939, Business cycle: A theoretical, historical, and statistical analysis of the capitalist process, New York: McGraw-Hill.

Shleifer, A., 1986, Implementation cycles, Journal of Political Economy, 94(6): 1163-1190.

Siegler, M.V., 2005, International growth and volatility in historical perspective, Applied Economics Letters, 12: 67-71.

Tabassum, A., and M.T. Majeed, 2008, Economic growth and income inequality relationship: Role of credit market imperfection, The Pakistan Development Review, 47(4): 727-743.

Talvi, E., and C.A. Végh, 2000, Tax base variability and procyclical fiscal policy, NBER working paper 7499, (Published in Journal of Development Economics, 2005, 78: 156-190). 
Tochkov, K. and K.Tochkov, 2009, Is higher volatility associated with lower growth? Intra-national evidence from South Korea, The Empirical Economics Letters, 8(7): 625-29.

Tsangarides, C.G., M. Saxegaard, and S. Roudet, 2007, Estimation of equilibrium exchange rates in the WAEMU: A robustness approach, International Monetary Fund.

Turnovsky, S., and P. Chattopadhyay,1998, Volatility and growth in developing economies: Some numerical results and empirical evidence, Working paper 0055, University of Washington, Department of Economics.

World Bank, 2012, World Development Indicators (WDI), Online Database, Washington DC: World Bank Group, Available at http://databank.worldbank.org/. 


\section{APPENDICES}

\section{TABLE A-1}

Summary of Empirical Literature Reviewed

\begin{tabular}{|c|c|c|c|}
\hline Study Name & $\begin{array}{c}\text { Data and } \\
\text { Methodology }\end{array}$ & Empirical Finding & $\begin{array}{c}\text { Explanation/ } \\
\text { Reasoning }\end{array}$ \\
\hline $\begin{array}{l}\text { Ramey and } \\
\text { Ramey (1995) }\end{array}$ & $\begin{array}{l}\text { A sample of } 92 \\
\text { economies and in an- } \\
\text { other sample of } 24 \\
\text { OECD economies; } \\
\text { Cross-section. }\end{array}$ & $\begin{array}{l}\text { Countries having } \\
\text { higher volatility have } \\
\text { lower growth. }\end{array}$ & $\begin{array}{l}\text { Volatility persuaded by } \\
\text { government expendi- } \\
\text { tures is negatively } \\
\text { linked with growth. }\end{array}$ \\
\hline $\begin{array}{l}\text { Turnovsky and } \\
\text { Chattopadhyay } \\
\text { (1998) }\end{array}$ & $\begin{array}{l}\text { A sample of } 61 \text { devel- } \\
\text { oping countries } \\
\text { Cross-section. }\end{array}$ & $\begin{array}{l}\text { For high volatile } \\
\text { economies, the study } \\
\text { found government ex- } \\
\text { penditure volatility, } \\
\text { monetary volatility and } \\
\text { terms of trade volatility } \\
\text { all to have strong nega- } \\
\text { tive effects on the equi- } \\
\text { librium growth rate. }\end{array}$ & $\begin{array}{l}\text { Developing } \\
\text { economies have neg- } \\
\text { ative link as ex- } \\
\text { plained in theoretical } \\
\text { framework. }\end{array}$ \\
\hline Caballero (2001) & $\begin{array}{l}\text { Case-studies of three } \\
\text { Latin American coun- } \\
\text { tries (Argentina, } \\
\text { Mexico and Chile). }\end{array}$ & $\begin{array}{l}\text { Worsening impact of } \\
\text { uncertainty (volatil- } \\
\text { ity) on economic } \\
\text { growth. }\end{array}$ & $\begin{array}{l}\text { Due to the country's } \\
\text { structural characteris- } \\
\text { tics, like poor financial } \\
\text { development, pro-cycli- } \\
\text { cal fiscal policy and de- } \\
\text { ficient rule of law, } \\
\text { which usually goes to- } \\
\text { gether with large public } \\
\text { indebtedness. }\end{array}$ \\
\hline $\begin{array}{l}\text { Hnatkovska and } \\
\text { Loayza (2004) }\end{array}$ & $\begin{array}{l}\text { Cross-country correla- } \\
\text { tion between volatility } \\
\text { and long-run economic } \\
\text { growth using cross sec- } \\
\text { tional data, especially, } \\
\text { the country-averages for } \\
\text { the period of } 1960-2000 \\
\text { of } 79 \text { nations along with } \\
22 \text { OECD countries. }\end{array}$ & $\begin{array}{l}\text { GDP volatility and } \\
\text { long-run economic } \\
\text { growth rate are nega- } \\
\text { tively related. }\end{array}$ & $\begin{array}{l}\text { Institutionally poor ex- } \\
\text { periencing intermediary } \\
\text { level of financial devel- } \\
\text { opment, underdevel- } \\
\text { oped economies or } \\
\text { inability to carry out } \\
\text { counter cyclical fiscal } \\
\text { policies. }\end{array}$ \\
\hline
\end{tabular}


TABLE A-1

(Continued)

\begin{tabular}{|c|c|c|c|}
\hline Study Name & $\begin{array}{c}\text { Data and } \\
\text { Methodology }\end{array}$ & Empirical Finding & $\begin{array}{l}\text { Explanation/ } \\
\text { Reasoning }\end{array}$ \\
\hline Döpke (2004) & $\begin{array}{l}\text { Quarterly time-series } \\
\text { data of the G7-coun- } \\
\text { tries covering the pe- } \\
\text { riod of 1970-I to } \\
\text { 2001-IV; VAR } \\
\text { Model. }\end{array}$ & $\begin{array}{l}\text { Business cycle shock } \\
\text { has a small negative ef- } \\
\text { fect on long-run pro- } \\
\text { ductivity. However, the } \\
\text { results appeared to be } \\
\text { not robust with changes } \\
\text { in the empirical model. }\end{array}$ & $\begin{array}{l}\text { G-7 (Developed } \\
\text { economies), therefore, } \\
\text { results are not robust. } \\
\text { (in agreement with the- } \\
\text { oretical framework). }\end{array}$ \\
\hline $\begin{array}{l}\text { Fatás and Mihov } \\
(2005)\end{array}$ & $\begin{array}{l}\text { Cross-section of } 91 \\
\text { nations. }\end{array}$ & $\begin{array}{l}\text { Policy-volatility have } \\
\text { a strong and direct } \\
\text { negative impact on } \\
\text { economic growth. }\end{array}$ & $\begin{array}{l}\text { Policy volatility appears } \\
\text { as a primary determi- } \\
\text { nant of macroeconomic } \\
\text { performance. The study } \\
\text { signified the role of po- } \\
\text { litical institutions in de- } \\
\text { termining the policy } \\
\text { outcomes. }\end{array}$ \\
\hline $\begin{array}{l}\text { Kose, Prasad and } \\
\text { Terrones (2005) }\end{array}$ & $\begin{array}{l}\text { Annual data for a period } \\
\text { of } 1960-2000 \text { on a sam- } \\
\text { ple of } 85 \text { economies ( } 21 \\
\text { industrial and } 64 \text { devel- } \\
\text { oping). }\end{array}$ & $\begin{array}{l}\text { There is a negative rela- } \\
\text { tionship between } \\
\text { growth and volatility } \\
\text { during this whole pe- } \\
\text { riod but the nature of } \\
\text { this relationship kept on } \\
\text { changing over time and } \\
\text { across different country- } \\
\text { groups. }\end{array}$ & $\begin{array}{l}\text { As explained in theo- } \\
\text { retical framework. }\end{array}$ \\
\hline Siegler (2005) & $\begin{array}{l}\text { Panel data set of } 12 \\
\text { nations over the pe- } \\
\text { riod of } 1870-1929 .\end{array}$ & $\begin{array}{l}\text { There is a significant } \\
\text { negative relationship } \\
\text { between growth and } \\
\text { volatility, even after } \\
\text { controlling for the other } \\
\text { related factors. }\end{array}$ & $\begin{array}{l}\text { Result confirmed the re- } \\
\text { sults of recent empirical } \\
\text { studies of the post- } \\
\text { World War II period. }\end{array}$ \\
\hline $\begin{array}{l}\text { Tochkov and } \\
\text { Tochkov (2009) }\end{array}$ & $\begin{array}{l}\text { provincial data from } \\
\text { South Korea over a } \\
\text { period of 1985-2003. }\end{array}$ & $\begin{array}{l}\text { Provinces with higher } \\
\text { volatility had lower } \\
\text { growth. }\end{array}$ & $\begin{array}{l}\text { Results for common } \\
\text { shocks across all } \\
\text { provinces shows the } \\
\text { agreement with theoret- } \\
\text { ical framework. }\end{array}$ \\
\hline
\end{tabular}


TABLE A-1

(Continued)

\begin{tabular}{|c|c|c|c|}
\hline Study Name & $\begin{array}{c}\text { Data and } \\
\text { Methodology }\end{array}$ & Empirical Finding & $\begin{array}{l}\text { Explanation/ } \\
\text { Reasoning }\end{array}$ \\
\hline $\begin{array}{l}\text { Dejuan and Gurr } \\
(2004)\end{array}$ & $\begin{array}{l}10 \text { Canadian } \\
\text { provinces' data over } \\
\text { the period of 1961- } \\
2000 \text {. }\end{array}$ & $\begin{array}{l}\text { The results of cross-sec- } \\
\text { tion and panel-data esti- } \\
\text { mations indicated a } \\
\text { weak positive relation- } \\
\text { ship between growth } \\
\text { and volatility. }\end{array}$ & $\begin{array}{l}\text { Developed country } \\
\text { data (in agreement } \\
\text { with theoretical } \\
\text { framework). }\end{array}$ \\
\hline $\begin{array}{l}\text { Herrero and Vi- } \\
\text { larrubia (2005) }\end{array}$ & $\begin{array}{l}\text { Over } 100 \text { countries } \\
\text { during the period } \\
1978-2002 \text {. }\end{array}$ & $\begin{array}{l}\text { A low or moderate level } \\
\text { of volatility can actually } \\
\text { enhance the economic } \\
\text { growth whereas very } \\
\text { high volatility is defi- } \\
\text { nitely detrimental to the } \\
\text { economic growth. }\end{array}$ & $\begin{array}{l}\text { Shows the existence } \\
\text { of a "Laffer Curve" } \\
\text { type relationship be- } \\
\text { tween volatility and } \\
\text { growth. }\end{array}$ \\
\hline Imbs (2006) & $\begin{array}{l}47 \text { countries using a } \\
\text { yearly sectoral data-set } \\
\text { of manufacturing activi- } \\
\text { ties published by } \\
\text { UNIDO for the period } \\
\text { from } 1970 \text { to } 1992 \text {. }\end{array}$ & $\begin{array}{l}\text { At the sectoral level, the } \\
\text { growth and volatility } \\
\text { links positively. This } \\
\text { positive correlation was } \\
\text { statistically significant } \\
\text { and economically siz- } \\
\text { able, especially in a re- } \\
\text { duced sample of OECD } \\
\text { countries, whereas, for } \\
\text { aggregate level, the } \\
\text { same data set provided } \\
\text { support for the well- } \\
\text { known negative rela- } \\
\text { tionship between } \\
\text { aggregate growth and } \\
\text { aggregate volatility. }\end{array}$ & $\begin{array}{l}\text { Inclusion of OECD } \\
\text { countries in sample } \\
\text { (as per theoretical } \\
\text { framework, advanced } \\
\text { economies may have } \\
\text { positive link). }\end{array}$ \\
\hline Lee (2010) & $\begin{array}{l}\text { Panel data of G7 } \\
\text { countries over the pe- } \\
\text { riod } 1965-2007 \text {. }\end{array}$ & $\begin{array}{l}\text { There is a positive link } \\
\text { between higher output } \\
\text { growth and higher } \\
\text { volatility of the innova- } \\
\text { tions to growth. }\end{array}$ & $\begin{array}{l}\text { Developed country } \\
\text { data (in agreement } \\
\text { with theoretical } \\
\text { framework). }\end{array}$ \\
\hline
\end{tabular}




\section{TABLE A-2}

Variable Description

\begin{tabular}{|c|c|c|}
\hline Acronym & Variable Description/Measurement & Source \\
\hline FLUC & $\begin{array}{l}\text { GDP Fluctuations: Five-years moving } \\
\text { standard deviation (SD) of per Capita } \\
\text { GDP growth from trend (five-years } \\
\text { moving SD of cyclical component, } \\
\text { decomposed by HP filter) is used as } \\
\text { an indicator of GDP. }\end{array}$ & $\begin{array}{l}\text { Authors' Calculation based on } \\
\text { WDI* data on GDP per capita } \\
\text { growth. }\end{array}$ \\
\hline LGR & $\begin{array}{l}\text { Long-run Growth: Usually measured by } \\
\text { mean growth rate. But, here the annual } \\
\text { data is required, therefore, five-years } \\
\text { moving average (mean) of GDP per } \\
\text { capita growth rate is used as an indicator } \\
\text { of Long-run Growth. }\end{array}$ & $\begin{array}{l}\text { Authors' Calculation based on } \\
\text { WDI data on growth rate of GDP } \\
\text { per capita. }\end{array}$ \\
\hline FINDEV & $\begin{array}{l}\text { Financial Development: Domestic private } \\
\text { credit to GDP ratio ( } \%) \text { is used as indica- } \\
\text { tor of Financial Development. }\end{array}$ & WDI 2012, Online \\
\hline IGDPP & $\begin{array}{l}\text { Initial GDP per capita: Natural loga- } \\
\text { rithm of ten year rolling back window } \\
\text { of GDP per capita (GDPP) is used as } \\
\text { an indicator Initial GDP per capita, } \\
\text { i.e. current year initial GDP per capita } \\
\text { is the ten year back GDP per capita } \\
\text { (Khan, 2010). }\end{array}$ & WDI 2012, Online \\
\hline OPEN & $\begin{array}{l}\text { Trade Liberalization / Openness: Vol- } \\
\text { ume of Exports + Imports as a share } \\
\text { of GDP }(\%) \text { is used as an indicator of } \\
\text { Trade Openness. }\end{array}$ & WDI 2012, Online \\
\hline INVT & $\begin{array}{l}\text { Investment: Gross Fixed Capital For- } \\
\text { mation as percentage of GDP is taken } \\
\text { as an indicator of Investment. }\end{array}$ & WDI 2012, Online \\
\hline GOVT & $\begin{array}{l}\text { Size of Government: Final consumption } \\
\text { expenditures by government as a percent- } \\
\text { age of GDP is used as an indicator of Size } \\
\text { of Government. }\end{array}$ & WDI 2012, Online \\
\hline POPGR & Population growth rate (in \%) & WDI 2012, Online \\
\hline
\end{tabular}

* World Development Indicators. 